\title{
Teaching NeuroImages: Leber hereditary optic neuropathy masquerading as neuromyelitis optica
}

Roman Kassa, MD, PhD, Flavius Raslau, MD, Charles Smith, MD, and Padmaja Sudhakar, MD

Neurology ${ }^{\circledast}$ 2018;90:e94-95. doi:10.1212/WNL.0000000000004760
Correspondence

Dr. Kassa

roman.kassa@uky.edu

Figure $1 \mathrm{MRI}$ findings in the spinal cord and optic nerves
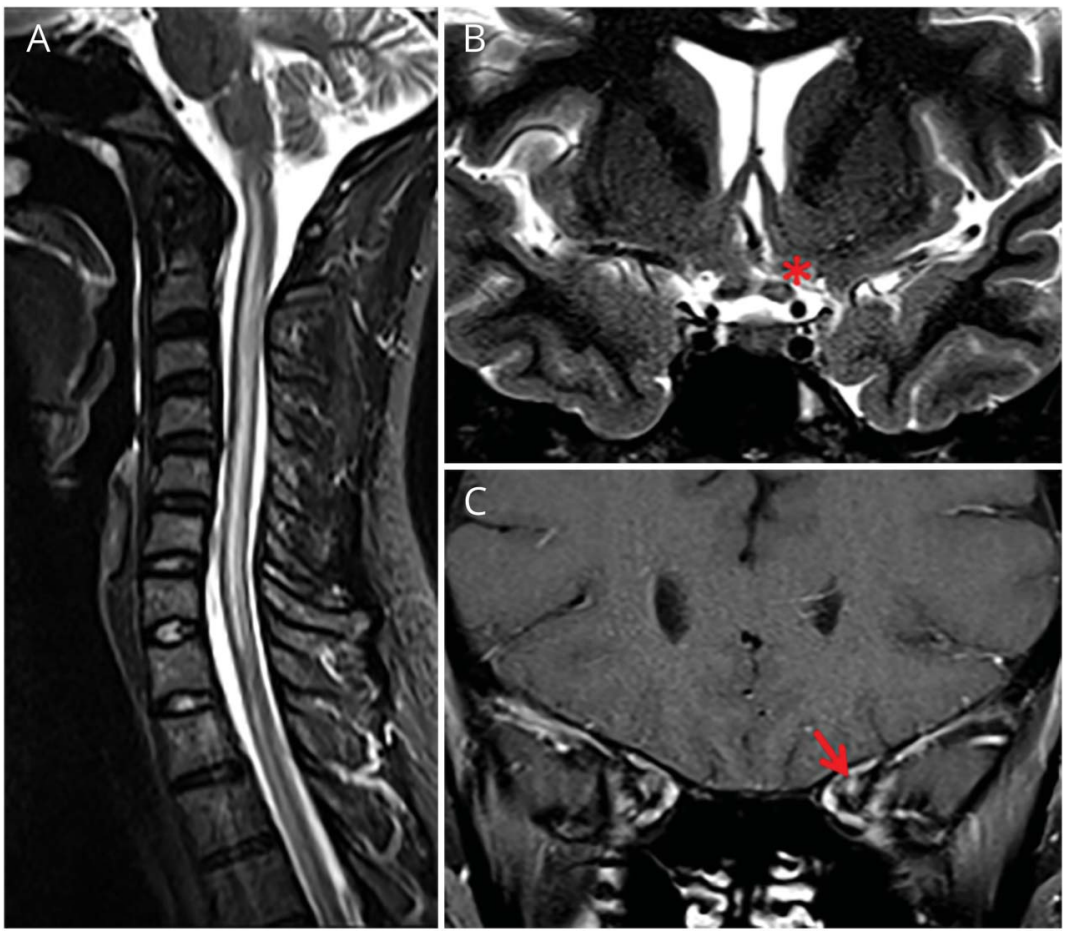

Sagittal T2-weighted images of the cervical spine (A) show extensive gray matter hyperintensity in the spinal cord and mild swelling. Coronal T2-weighted images of the orbits (B) show central hyperintensity in the optic nerves near the chiasm (asterisk). Coronal postcontrast T1-weighted images (C) show enhancement of the apical segment of the left optic nerve (arrow).

A 22-year-old woman presented with photopsia, sensory loss, and paresthesia over both lower extremities, visual scotomas, and painless binocular vision loss over 5 months. MRI showed T2 hyperintensities near the optic chiasm (figure 1, B and C), floor of the fourth ventricle and the colliculi (figure 2, A-F), and central gray matter of the spinal cord (figure 1A). CSF analysis was notable for elevated glucose and lactate; oligoclonal bands, immunoglobulin $\mathrm{G}$ index, and aquaporin-4 antibodies were negative. Her maternal uncle has Leber hereditary optic neuropathy (LHON) and a genetic analysis confirmed an m.3460 G>A mitochondrial DNA point mutation.

LHON commonly presents with subacute bilateral vision loss due to free radical oxidative injury causing selective retinal ganglion cell loss. ${ }^{1}$ However, Leber "plus" disease with combined optic neuropathy and extensive myelopathy is rare. ${ }^{2}$ The mechanism of cord injury is unknown.

\section{MORE ONLINE}

$\rightarrow$ Download teaching slides:

links.lww.com/WNL/A16 


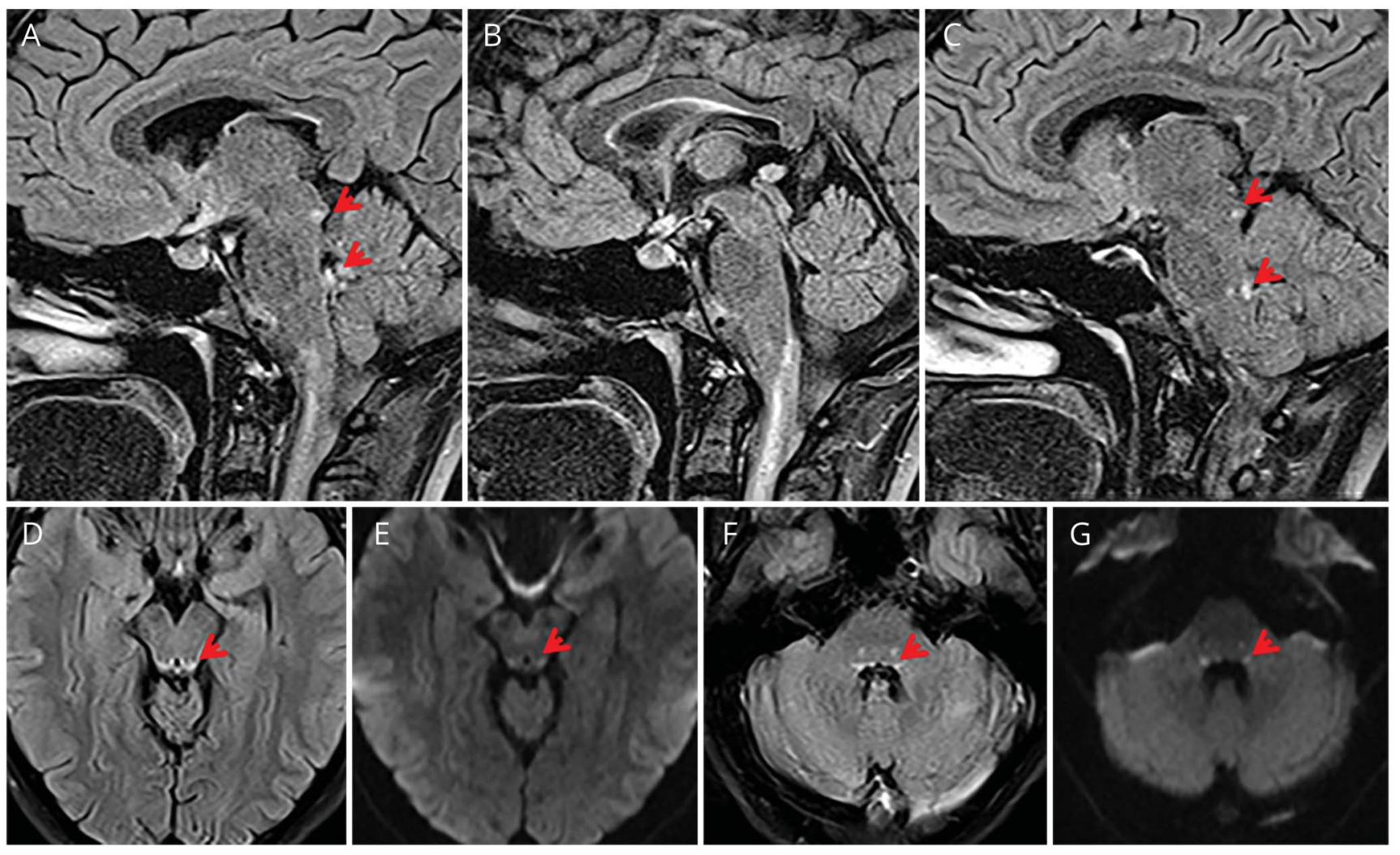

Sagittal T2-weighted fluid-attenuated inversion recovery (FLAIR) images of the brain (A-C, left to right) and axial T2-weighted FLAIR images (D and F) show symmetric hyperintensities along the floor of the fourth ventricle in the region of the vestibular nuclei and in the colliculi (arrowheads). Axial diffusionweighted imaging ( $E$ and $\mathrm{G}$ ) shows corresponding restricted diffusion. There is edema in the visualized cord (B).

\section{Author contributions}

Roman Kassa: study concept and design, acquisition of data. Flavius Raslau: analysis and interpretation of data. Charles Smith: study concept and design, acquisition of data. Padmaja Sudhakar: study concept and design, acquisition of data.

\section{Study funding}

No targeted funding reported.

\section{Disclosure}

The authors report no disclosures relevant to the manuscript. Go to Neurology.org/N for full disclosures.

\section{References}

1. Levy LA. Mechanisms of retinal specific-cell death in Leber hereditary optic neuropathy. Trans Am Ophthalmol Soc 2007;105:379-391.

2. McClelland CM, Van Stavern GP, Tselis AC. Leber hereditary optic neuropathy mimicking neuromyelitis optica. J Neuroophthalmol 2011;31:265-268. 


\section{Neurology}

\section{Teaching NeuroImages: Leber hereditary optic neuropathy masquerading as neuromyelitis optica}

Roman Kassa, Flavius Raslau, Charles Smith, et al.

Neurology 2018;90;e94-e95

DOI 10.1212/WNL.0000000000004760

\section{This information is current as of December 28, 2017}

\section{Updated Information \&} Services

References

Subspecialty Collections

Permissions \& Licensing

Reprints including high resolution figures, can be found at: http://n.neurology.org/content/90/1/e94.full

This article cites 2 articles, 0 of which you can access for free at: http://n.neurology.org/content/90/1/e94.full\#ref-list-1

This article, along with others on similar topics, appears in the following collection(s):

All Demyelinating disease (CNS)

http://n.neurology.org/cgi/collection/all_demyelinating_disease_cns Devic's syndrome

http://n.neurology.org/cgi/collection/devics_syndrome

Mitochondrial disorders

http://n.neurology.org/cgi/collection/mitochondrial_disorders MRI

http://n.neurology.org/cgi/collection/mri

Optic nerve

http://n.neurology.org/cgi/collection/optic_nerve

Information about reproducing this article in parts (figures,tables) or in its entirety can be found online at:

http://www.neurology.org/about/about_the_journal\#permissions

Information about ordering reprints can be found online:

http://n.neurology.org/subscribers/advertise

Neurology ${ }^{\circledR}$ is the official journal of the American Academy of Neurology. Published continuously since 1951, it is now a weekly with 48 issues per year. Copyright Copyright ( 2017 American Academy of Neurology. All rights reserved. Print ISSN: 0028-3878. Online ISSN: 1526-632X.

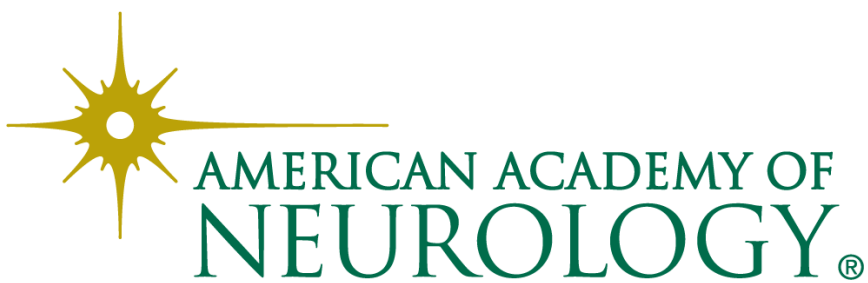

